\title{
Green propolis ethanolic extract in bean plant protection against bacterial diseases
}

\author{
Jonas Marcelo Jaski ${ }^{1}$ (iD Fabio Junior Telaxka² (iD Gabriela Silva Moura ${ }^{3}$ (iD Gilmar Franzener G $^{*}$ iD \\ ${ }^{1}$ Programa de Pós-Graduação em Agronomia, Universidade Estadual de Maringá (UEM), Maringá, PR, Brasil. \\ ${ }^{2}$ Programa de Pós-graduação em Agronomia, Universidade Estadual do Centro-Oeste (UNICENTRO), Guarapuava, PR, Brasil. \\ ${ }^{3}$ Universidade Federal da Fronteira Sul (UFFS), Campus Laranjeiras do Sul, 85301-970, Laranjeiras do Sul, PR, Brasil. E-mail: \\ gilmar.franzener@uffs.edu.br. "Corresponding author.
}

ABSTRACT: The aim of this study was to evaluate the ethanolic extract of green propolis (EEP) in the protection of common bean plants against two main bacterial cultures, bacterial blight (Xanthomonas axonopodis pv. phaseoli) and wildfire (Pseudomonas syringae pv. tabaci). Experiments on antimicrobial activity were performed, inducing phytoalexins, defense-related enzymes, and disease severity, under concentrations of $0,0.5,1.0,2.5$, and 5.0\%. The EEP presented antimicrobial activity on both phytobacteria, causing a decrease in their development. It has also promoted a linear accumulation of phaseolin in bean hypocotyls according to the EEP concentration used. There was a reduction in the lesion area, which was caused by bacterial blight on bean leaves treated with EEP, and local and systemic effect were observed. Polyphenoloxidase was activated with 5\% EEP, reaching the maximum activation time 62.5 h after application. An increase was observed in the activity of phenylalanine ammonia-lyase in plants treated with EEP, with local and systemic effect. Results indicated the potential of EEP in the control of these diseases.

Key words: alternative control, wildfire, bacterial blight, resistance induction.

Extrato etanólico de própolis verde na proteção de feijoeiro contra bacterioses

RESUMO: Este trabalho teve como objetivo avaliar o extrato etanólico de própolis verde (EEP) na proteção de plantas de feijoeiro contra as duas principais bacterioses da cultura, crestamento bacteriano (Xanthomonas axonopodis pv. phaseoli) e fogo selvagem (Pseudomonas syringae pv. tabaci). Foram realizados experimentos sobre atividade antimicrobiana indutora de fitoalexinas, de enzimas relacionadas à defesa, e na severidade da doença, usando as concentrações de 0, 0,5, 1,0, 2,5 e 5,0\%. O EEP apresentou atividade antimicrobiana sobre ambas fitobactérias, causando uma redução em seu desenvolvimento. O EEP também promoveu um acúmulo linear de faseolina em hipocótilos de feijoeiro conforme a concentração usada. Houve uma redução na área lesionada pelo crestamento bacteriano em folhas de feijoeiro tratadas com EEP, com efeito local e sistêmico. A enzima polifenoloxidase foi ativada pelo EEP a 5\%, com ponto máximo de ativação 62,5 horas após aplicação. Houve um aumento na atividade de fenilalanina amônia-liase em plantas tratadas com EEP, com efeito local e sistêmico. Os resultados indicam o potencial do EEP no controle dessas doenças.

Palavras-chave: controle alternativo, fogo selvagem, crestamento bacteriano, indução de resistência.

\section{INTRODUCTION}

The bean crop (Phaseolus vulgaris L.) is of great importance in family agriculture and food sovereignty, being one of the main legumes grown in Brazil (GODINHO et al., 1998). Frequently, diseases occur in the bean crop, including bacterial diseases, common bacterial blight (Xanthomonas axonopodis pv. phaseoli), and wildfire (Pseudomonas syringae pv. tabaci) (WENDLAND et al., 2016). These diseases usually cause great damage to the culture, because they are difficult to control, development of resistant cultivars is difficult, and chemical control of these diseases has a low efficiency (VALARINI \& MENTEN, 1991).

In this context, the use of more sustainable techniques, with less impact on the environment, is necessary. This requires the development of new products to be incorporated as strategies for alternative control of plant diseases, including new substances with antimicrobial potential (FRANZENER et al., 2018; VIECELLI et al., 2009).

Propolis stands out among natural substances with antimicrobial potential (JARDIM, 2014). It is a complex substance produced by bees and deposited in their hives. There is little 
information on the use of propolis in agriculture, but some studies indicated its potential in the control of plant diseases (GUGINSKI-PIVA et al., 2015; PEREIRA et al., 2013). Green propolis is a type of propolis, which is extracted by bees mainly from the native shrub Baccharis dracunculifolia DC. (SIMÕES-AMBROSIO et al., 2010). It has various medicinal properties (CHEUNG et al., 2011). However, information about its potential effect on plant protection is scarce.

Propolis is easy to obtain and carries out different biological activities. Thus, it may be an alternative in the control of phytopathogenic bacteria (BALDIN et al., 2014). Therefore, the objective of this study was to contribute to the knowledge about the potential of green propolis in the alternative control of bacterial diseases of bean plants.

\section{MATERIALS AND METHODS}

Experiments were carried out in the Phytopathology Laboratory and in the greenhouse (Federal University of Fronteira Sul, Campus of Laranjeiras do Sul, PR). The geographical coordinates of the region are as follows: 25'26'42.0" South latitude and 52 $26^{\prime} 29.4^{\prime \prime}$ West longitude. According to the Köppen classification, the experimental area is located in the region of humid subtropical climate.

Commercial green propolis, from the region of Ribeirão Preto, SP, was used as an ethanolic extract (EEP), containing 11\% dry extract $(w / v)$. Dilutions in distilled water were made from the EEP for use in the experiments. The bacteria $X$. axonopodis pv. phaseoli and $P$. syringae pv. tabaci were isolated from symptomatic leaves of common bean in the municipality of Laranjeiras do Sul, PR, being cultivated in agar nutrient medium. Antimicrobial activity experiment was performed in sterile test tubes containing culture medium nutrient broth. The EEP with different concentrations $(0,0.1$, $0.5,1.0,2.5$, and $5.0 \%$ ) were added to these test tubes with a total final volume of $5 \mathrm{~mL}$ per tube. Each tube received a bacterial suspension $(100 \mu \mathrm{L})$ in saline

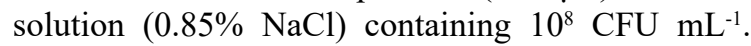
Tubes were shaken $\left(27^{\circ} \mathrm{C} ; 48 \mathrm{~h}\right)$ and absorbance $(\lambda=580 \mathrm{~nm})$ of the suspensions was then determined when a reference sample, without bacteria (blank), was used for each treatment.

In the assay to induce phytoalexins, seeds of the Crioula Carioca bean variety were first disinfested in $1 \%$ sodium hypochlorite solution ( $5 \mathrm{~min}$ ), and then washed in sterile distilled water. Seeds were sown in autoclaved sand $\left(120^{\circ} \mathrm{C} ; 20 \mathrm{~min}\right)$ and kept in incubation $\left(24^{\circ} \mathrm{C}\right.$; in the dark). After sowing (7 days), four hypocotyl segments (about $5 \mathrm{~cm}$ ) were packed in Petri dishes containing filter paper moistened with sterile distilled water. Then, treatment solutions were sprayed onto the hypocotyls. Petri dishes were incubated in a germination chamber $\left(25^{\circ} \mathrm{C}\right.$; in the dark). After $48 \mathrm{~h}$, the hypocotyls were transferred to 20 -mL tubes containing $70 \%$ ethyl alcohol $(10 \mathrm{~mL})$ for phytoalexin extraction. Tubes were kept refrigerated $\left(4{ }^{\circ} \mathrm{C} ; 48 \mathrm{~h}\right)$ and then stirred $(1 \mathrm{~h})$. Phaseolin content was determined using a spectrophotometer $(\lambda=280$ $\mathrm{nm})$, according to the methodology proposed by DIXON et al. (1983), with modifications. To evaluate the protective effect of EEP, common bean plants cv. Crioula Carioca were cultivated in 2-L pots containing soil, organic matter, and sand (2:1:1), and were then kept in a controlled greenhouse. Treatments started when the plants presented two trifolia. The EEP concentrations $(0,0.5,1.0,2.5$, and $5.0 \%)$ were applied by spraying on the first bean trifolium. Three days later, the treated leaves (including the second bean trifolium) were sprayed with a suspension of $X$. axonopodis pv. phaseoli $\left(1 \times 10^{8} \mathrm{UFC} \mathrm{mL}^{-1}\right)$. After the symptoms appeared (10 days), the severity of the disease was evaluated using the QUANT v.1.0.1 (UFV) computer program (VALE et al., 2001).

Treatments to evaluate the synthesis of defense enzymes in common bean plants were as follows: 5\% of EEP in distilled water and alcoholic solution (1\% ethanol), which were applied in the first trifolium. The following disks were collected: 8 leaf discs (diameter: $2 \mathrm{~cm}$ ) of each plot, 4 discs of the treated trifolium, and 4 discs of the untreated trifolium. The discs were collected $0,24,48,72$, and $96 \mathrm{~h}$ after treatments were applied, packed in an aluminum foil, and kept at $-20{ }^{\circ} \mathrm{C}$ until the biochemical analyzes were performed. The activities of polyphenol oxidase and phenylalanine ammonia-lyase were determined according to the methodologies proposed by DUANGMAL \& APENTEN (1999) e UMESHA (2006), respectively. Tests (five replicates) were conducted in a completely randomized design, with distilled water (control) and ethanol solution diluted in distilled water $(1 \%$ ethanol). After the results were obtained, variance analysis followed by regression analysis was performed. The analyzes were performed using the Sisvar program (FERREIRA, 2007).

\section{RESULTS AND DISCUSSION}

In the assay of EEP antimicrobial activity on phytobacteria, a decrease was observed in the 
development of both species (Figure 1A). The exponential curve showed inhibition of bacterial growth with the lowest EEP concentrations, and total inhibition with $5.0 \%$ concentration. A $77.3 \%$ inhibition, relative to the treatment without propolis ( $1 \%$ ethanol), was observed with $0.5 \%$ concentration, which was more expressive $(96.8 \%$ and $99.1 \%)$ on $X$. axonopodis pv. phaseoli with $2.5 \%$ and $5.0 \%$ concentrations, respectively. A similar result was observed in P. syringae pv. tabaci (Figure 1B). The highest inhibition $(99.6 \%)$ for this bacterium was observed at $5 \%$ concentration.

The propolis antimicrobial effect is already well known, but mainly on bacteria of medical importance (CHEUNG et al., 2011). BALDIN et al. (2014) evaluated the effect of crude propolis ethanolic extract on $X$. axonopodis pv. phaseoli and observed inhibition of bacterial development, with greater effect in higher extract concentrations. JARDIM et al. (2014) observed a high antimicrobial potential of green propolis in the effect on Staphylococcus aureus in vitro. Use of green propolis in agriculture is still poorly understood. The biological activity of green propolis has been mainly attributed to phenolic compounds, which are also abundant in Baccharis dracuncunlifolia, its main botanical source. Bacarin, aromadendrin-4'-methyl ether, and artepilin $\mathrm{C}$ have been highlighted among the active compounds of green propolis (SIMÕESAMBROSIO et al., 2010).

Regarding phaseolin induction, an increase in the accumulation of this phytoalexin was observed with increase in the EEP concentration used (Figure 2). Phaseolin production was higher than $152 \%$ with $5 \%$ concentration, relative to the treatment without EEP ( $1 \%$ ethanol).

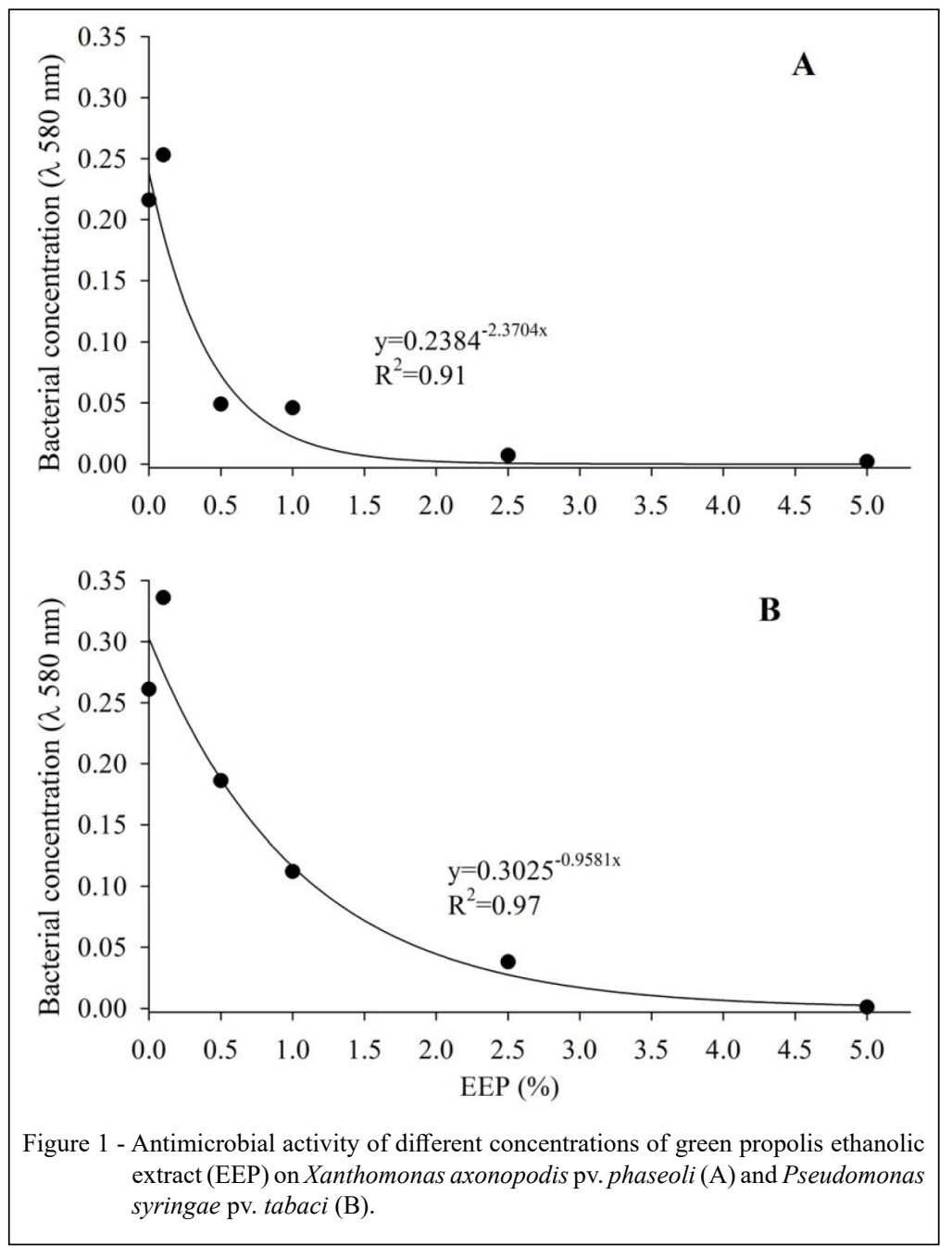

Ciência Rural, v.49, n.6, 2019. 


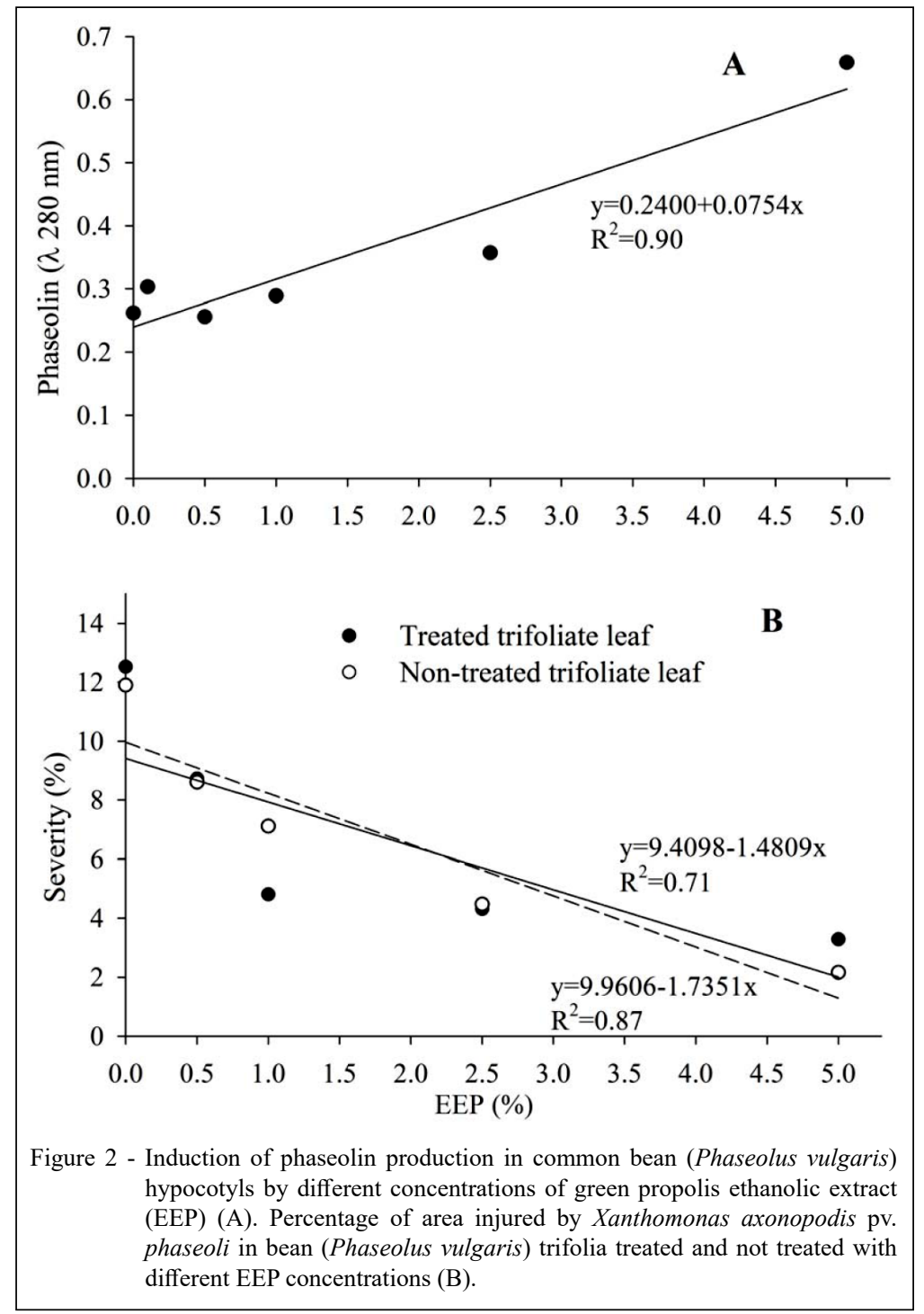

Induction of phytoalexins by propolis is still little known. In one of the few studies on this subject, GUGINSKI-PIVA et al. (2015) observed that propolis non-alcoholic extract promoted phytoalexin glyceolin accumulation in soybean (Glycine max) cotyledons, which was proportional to concentration used. BALDIN et al. (2014) also observed a linear increase in phytoalexin induction in common bean hypocotyls using brown propolis ethanolic extract. Regarding phaseolin induction with the use of green propolis, our results agreed with those obtained in studies cited here.

The EEP promoted a significant decrease in the area injured by the common bacterial blight ( $X$. axonopodis pv. phaseoli) in bean plants, in both treated and untreated trifolia, indicating the local and systemic effect of propolis on plants. At 5\% concentration, a decrease was observed in treated $(71.0 \%)$ and untreated leaves $(75.3 \%)$.

Results obtained showed the potential of green propolis in the protection of common bean. Although, the effect of green propolis on plants is little known, its potential has already been reported in human and animal health, in addition to its significant antimicrobial effect (JARDIM, 2014). The $4 \%$ ethanolic extract of brown propolis caused a $63 \%$ decrease in the severity of anthracnose in common bean plants, besides increasing the foliar content of magnesium $(\mathrm{Mg})$, nitrogen $(\mathrm{N})$, iron $(\mathrm{Fe})$, foliar area, and productivity (PEREIRA et al., 2014). 
The brown propolis ethanolic extract also showed an increase in leaf area and number of leaves in coffee seedlings, reducing the incidence of cercosporiosis (PEREIRA et al., 2013). Studies in this area are important to better know the effectiveness of propolis extract in vivo, in both disease severity decrease and crop productivity.

Polyphenol oxidase (PFO) was evaluated in bean treated or untreated trifolia with $5 \%$ green propolis ethanolic extract and the results are shown in figure 3 . The $5 \%$ green propolis ethanolic extract was able to activate PFO in common bean, and enzyme activity showed to be similar when $1 \%$ ethyl alcohol was applied. This could indicate that ethanol also activates this enzyme in plants. This effect was observed in both treated and untreated trifolia, indicating a systemic effect of both propolis and ethanol. However, propolis showed to have a greater effect.
A quadratic effect was observed in PFO, indicating that the maximum enzyme activity was in the range 24-72 $\mathrm{h}$ after treatment application. The times of highest enzyme activity were observed after application on the treated $(62.5 \mathrm{~h})$ and untreated $(60$ h) trifolia. These plant defense responses are usually activated soon after treatment with the inducing agent (OLIVEIRA et al., 2016), and induction is usually observed within $72 \mathrm{~h}$ after treatment (FRANZENER et al., 2018).

Our results showed that propolis has a potential to induce plant defense-related enzymes. Other alternatives for plant protection have also shown the possibility of inducing these enzymes. VIECELLI et al. (2009) used a filtrate of the basidiomycete Pycnoporus sanguineus and observed an increase in the polyphenol oxidase and peroxidase activities applying the filtrate in common bean plants. Application of Lippia alba tinctures

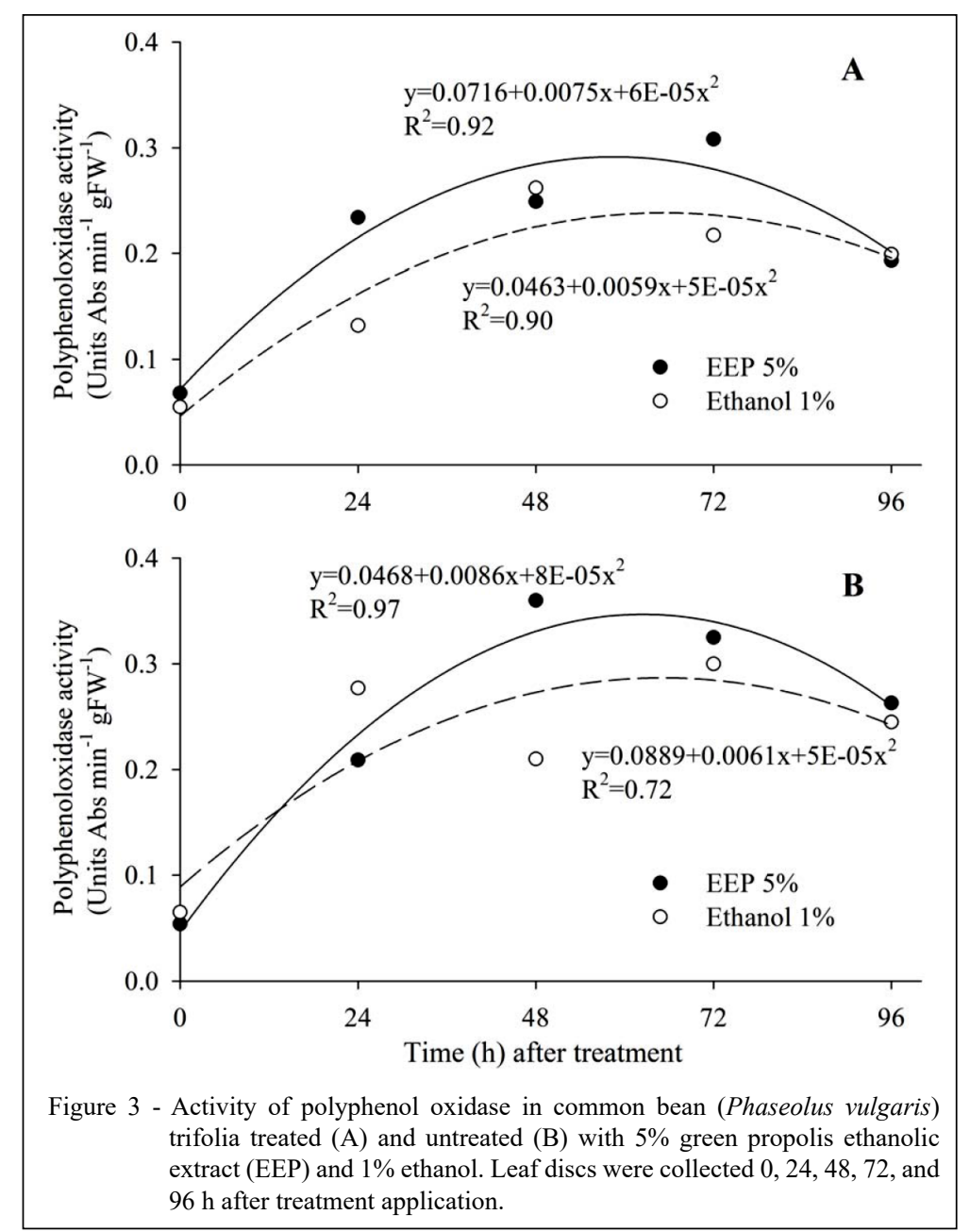

Ciência Rural, v.49, n.6, 2019. 
increased the synthesis of peroxidase, polyphenol oxidase, and total soluble proteins in common bean plants (VIGO et al., 2009).

Regarding induction of phenylalanine ammonia-lyase (PAL), a linear increase was observed in the enzyme activity of plants treated with EEP in trifolia evaluated. However, the most significant effect occurred on treated trifolia (Figure 4). Application of $1 \%$ ethanol showed a linear effect in the treated trefoil, but lower than that of the EEP. Results obtained for PAL induction by EEP are very important because this is a key enzyme between the primary and secondary metabolisms in plants (UMESHA, 2006) and it can trigger important routes related to plant defense. The linear trend line in both treated and untreated trifolia suggested local and systemic effects of green propolis on inducing defense enzymes.

ALMEIDA et al. (2012) evaluated PAL in different soybean genotypes and attributed the high enzyme activity to the expression of secondary metabolites essential to the cellular structure, including metabolites of phenolic origin. According to RODRIGUES et al. (2006), it is possible that PAL synthesis occurs late, thus contributing to explain the greater effect of green propolis ethanol extract $72 \mathrm{~h}$ after application, with a possible increase in the effect along time as indicated by the linear trend line. The increase in the activities of PAL, PFO, and other enzymes may be directly related to the induction of plant resistance (FRANZENER et al., 2018; OLIVEIRA et al., 2016).

\section{CONCLUSION}

The green propolis ethanolic extract showed antimicrobial activity on Xanthomonas axonopodis pv. phaseoli and Pseudomonas syringae pv. tabaci, and induces accumulation of phytoalexin

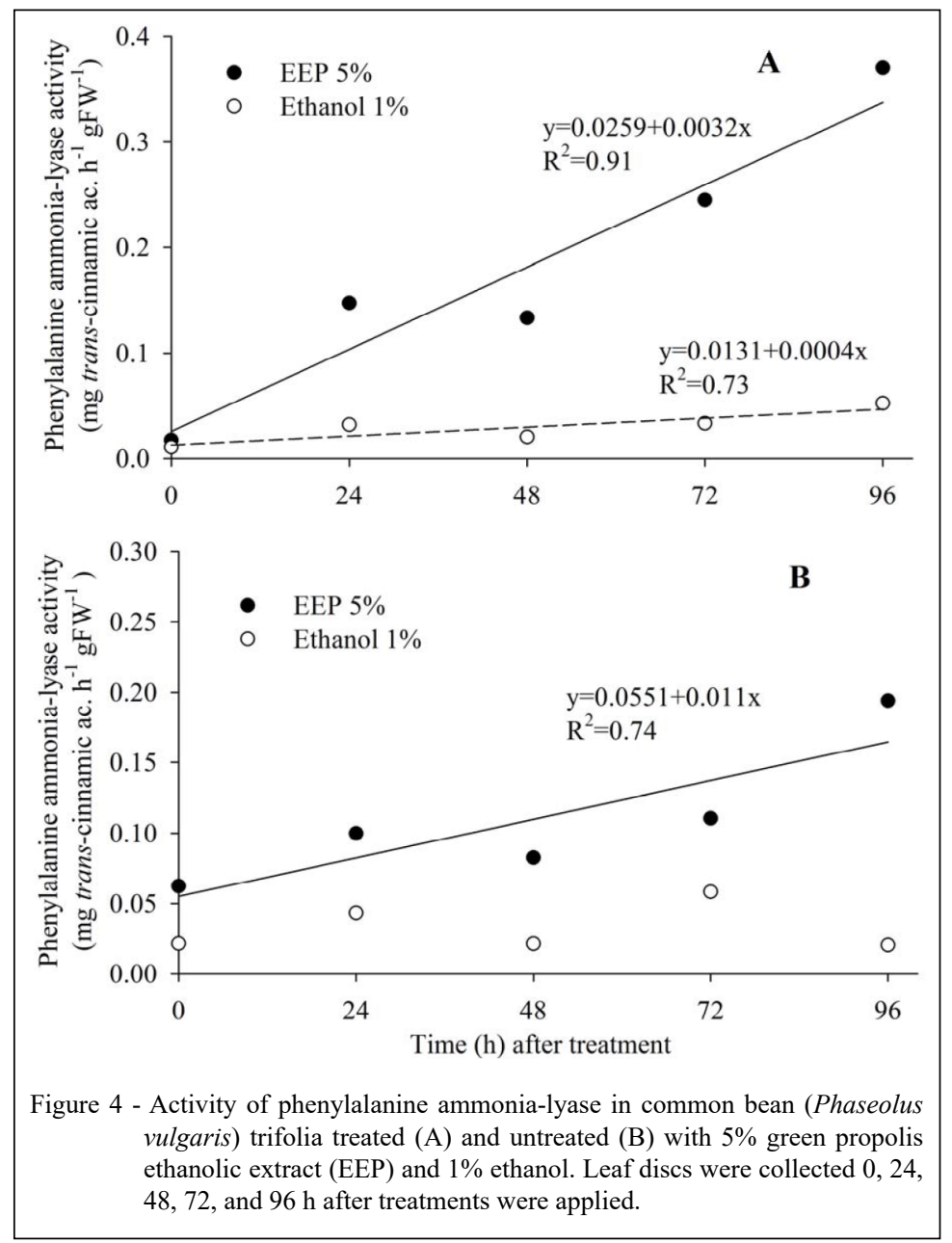

Ciência Rural, v.49, n.6, 2019. 
phaseolin in common bean hypocotyls. The green propolis ethanolic extract induces the formation of polyphenol oxidase and phenylalanine ammonialyase, with local and systemic effects in common bean plants, besides promoting a decrease in the area injured by bacterial blight.

\section{ACKNOWLEDGEMENTS}

To the Universidade Federal da Fronteira Sul (UFFS) for the scholarship of scientific initiation granted (PRO ICT-UFFS) and was financed in part by the Coordenação de Aperfeiçoamento de Pessoal de Nível Superior (CAPES), Brasil - Finance code 001.

\section{DECLARATION OF CONFLICT OF INTERESTS}

The authors declare no conflict of interest. The founding sponsors had no role in the design of the study; in the collection, analyses, or interpretation of data; in the writing of the manuscript, and in the decision to publish the results.

\section{AUTHORS' CONTRIBUTIONS}

The authors contributed equally to the manuscript.

\section{REFERENCES}

ALMEIDA, H.O. et al. Differentially regulated induced resistance marker enzymes in soybean genotypes resistant and susceptible to Asian soybean rust. Pesquisa agropecuária brasileira, v.47, n.2, p.163-172, 2012. Available from: <http://www.scielo.br/pdf/pab/ v47n2/v47n2a03.pdf $>$. Accessed: Mar. 18, 2018. doi: 10.1590/ S0100-204X2012000200003.

BALDIN, D. et al. Phaseolin induction in bean and antibacterial activity against Xanthomonas axonopodis pv. phaseoli by propolis ethanol extract. Cadernos de Agroecologia. v.9, p.15, 2014. Available from: <http://revistas.aba-agroecologia. org.br/index.php/cad/article/view/15576/10082>. Accessed: Apr. 16, 2017

CHEUNG, K.-W. et al. Brazilian green propolis and its constituent, Artepillin $\mathrm{C}$ inhibits allogeneic activated human CD4 T cells expansion and activation. Journal of Ethnopharmacology, v.138, n.2, p.463-471, 2011. Available from: $<$ https://doi.org/10.1016/j. jep.2011.09.031>. Accessed: Mar. 18, 2018. doi: 10.1016/j. jep.2011.09.031.

DIXON, R.A. et al. Phytoalexin indution in french bean: intercellular transmission of elicitation in cell suspension cultures and hypocotyl sections of Phaseolus vulgaris. Plant Physiology, v.71, n.2, p.251-256, 1983. Available from: <http:// www.plantphysiol.org/content/plantphysiol/71/2/251.full.pdf $>$. Acessed: Mar. 25, 2017.

DUANGMAL, K.; APENTEN, R. K. O. A comparative study of polyphenoloxidases from taro (Colocasia esculenta) and potato (Solanum tuberosum var. romano). Food Chemistry, v.64, p. 351-359, 1999. Available from: <https://doi.org/10.1016/S0308-
8146(98)00127-7>. Accessed: Jun. 25, 2017. doi: 10.1016/S03088146(98)00127-7.

FERREIRA, D.F. SISVAR: Sistema de análise de variância para dados balanceados, versão 5.0. Lavras: DEX/UFLA, 2007. CDROM. Software.

GODINHO, V.P.C. et al. Introdução e avaliação de cultivares de feijoeiro (Phaseolus vulgaris L.) do grupo carioca em Vilhena. Porto Velho: Embrapa Rondônia, 3 p. 1998.

GUGINSKI-PIVA, C.A. et al. Propolis for the control of powdery mildew and the induction of phytoalexins in cucumber. Idesia, v.33, n.1, p.39-47, 2015. Available from: <https://scielo.conicyt. $\mathrm{cl} / \mathrm{pdf} / \mathrm{idesia} / \mathrm{v} 33 \mathrm{n} 1 / \operatorname{art} 05 . \mathrm{pdf}>$. Accessed: Jun. 25, 2017. doi: 10.4067/S0718-34292015000100005.

JARDIM, D.M. Avaliação in vitro da atividade antibacteriana de diferentes própolis. MICROAL. Blucher Food Science Proceedings, n.1, v.1. São Paulo: Editora Blucher, 2014.

FRANZENER, G. et al. Induction of defense enzymes and control of anthracnose in cucumber by Corymbia citriodora aqueous extract. Summa Phytopathologica, v.44, n.1, p.10-16, 2018. Available from: <http://www.scielo.br/scielo.php?script=sci_artt ext\&pid=S0100-54052018000100010>. Accessed: Jun. 14, 2018. doi: $10.1590 / 0100-5405 / 2218$.

OLIVEIRA, M.D.M. et al. Induced resistance during the interaction pathogen $\mathrm{x}$ plant and the use of resistance inducers. Phytochemistry Letters, v.15, p.152-158, 2016. Available from: $<$ https://doi.org/10.1016/j.phytol.2015.12.011>. Accessed: Jun. 12, 2017. doi: 10.1016/j.phytol.2015.12.011.

PEREIRA, C.S. et al. Application of ethanol extract of propolis (EEP) on the nutrition, development and yield of common bean. Revista Ceres, v.61, n.1, p.098-104, 2014. Available from: <http:// www.scielo.br/pdf/rceres/v61n1/v61n1a13.pdf $>$. Accessed: Apr. 23, 2016. doi: 10.1590/S0034-737X2014000100013.

PEREIRA, C.S et al. Propolis ethanolic extract for the control of brown eye spot and on development of coffee seedlings. Revista Brasileira de Agroecologia, v.8, n.1, p.170-178, 2013. Available from: <http://revistas.aba-agroecologia. org.br/index.php/rbagroecologia/article/view/12872/8866>. Accessed: Mar. 05, 2015.

RODRIGUES, A.A.C. et al. Induced resistance to Fusarium oxysporum f. sp. tracheiphilum in cowpea plants: effectiveness of abiotic inducers and elicited enzymatic activity. Fitopatologia Brasileira, v.31, n.5, p.492-499, 2006. Available from: <http:// www.scielo.br/pdf/fb/v31n5/09.pdf>. Accessed: Apr. 20, 2016. doi: $10.1590 /$ S0100-41582006000500009.

SIMÕES-AMBROSIO, L.M.C. et al. The role of seasonality on the inhibitory effect of Brazilian green propolis on the oxidative metabolism of neutrophils. Fitoterapia, v.81, n.8, p.1102-1108, 2010. Available from: <https://doi.org/10.1016/j. fitote.2010.07.008>. Accessed: Jun. 19, 2016. doi: 10.1016/j. fitote.2010.07.008.

UMESHA, S. Phenylalanine ammonia lyase activity in tomato seedlings and its relationship to bacterial canker disease resistance. Phytoparasitica, v.34, p.68-71, 2006. Available from: <https:// link.springer.com/content/pdf/10.1007/BF02981341.pdf >. Accessed: Jun. 12, 2015.

Ciência Rural, v.49, n.6, 2019. 
VALARINI, P.J.; MENTEN, J.O. Inoculação artificial de sementes de feijão com Xanthomonas campestris pv. phaseoli e seu efeito sobre a qualidade sanitária e germinação. Summa Phytopathologica, v.17, p.227-231, 1991.

VALE, F.X.R. et al. Quantificação de doenças - Quant versão 1.0.1. Viçosa: UFV. 2001. Software.

VIECELLI, C.A. et al. Induction of resistance in beans against Pseudocercospora griseola by culture filtrates of Pycnoporus sanguineus. Tropical Plant Pathology, v.34, n.2, p.087-096, 2009. Available from: <http://www.scielo.br/pdf/tpp/v34n2/ v34n2a03.pdf> Accessed: Apr. 16, 2018. doi: 10.1590/S198256762009000200003

VIGO, S.C. et al. Action of medicinal plants tinctures and essential oils to the bean common bacterial blight and on protein production of resistance induction. Summa Phytopathologica, v.35 n.4, p.293-304. 2009. Available from: <http://www.scielo.br/pdf/sp/v35n4/a07v35n4.pdf $>$. accessed: Mar. 28, 2018. doi: 10.1590/S0100-54052009000400007.

WENDLAND, A. et al. Doenças do feijoeiro. In: AMORIM, L. et al. Manual de Fitopatologia: Doenças das Plantas Cultivadas. Ouro Fino: CERES, Cap.39, p.383-396, 2016. 